Part 4. Studia Iuridica Lublinensia vol. XXVII, 1, 2018 DOI: $10.17951 /$ sil.2018.27.1.191

\title{
Zygmunt Tobor
}

University of Silesia, Katowice, Poland

zygmunt.tobor@us.edu.pl

Mateusz Zeifert

University of Silesia, Katowice, Poland mateusz.zeifert@gmail.com

\section{How Polish Courts Use Previous Judicial Decisions?}

\author{
Jak polskie sądy stosują wcześniejsze orzeczenia?
}

\section{SUMMARY}

In this article, the authors analyse the manners of applying prior rulings in the process of law enforcement by the Polish courts. Three aspects of this issue are examined in sequence. Firstly, the manner of referring to rulings (e.g., quote, paraphrase, etc.). Secondly, situations, in which courts refer to other rulings (e.g., as a reference point, as an evidence of interpretative doubts, as a tool removing vagueness or ambiguity of a provision, as a methodological tip, as a legal basis of a ruling, etc.). Thirdly, the reasons for those acts of reference to appear. In conclusions, the authors juxtapose the analysis results with the practice of referring to judicial rulings, which is characteristic for countries applying the precedential law, and they also indicate basic differences between them.

Keywords: case law; argumentation; precedent

\section{INTRODUCTION}

There are few things more fascinating for a legal theorist from a statutory law country than the idea of judge-made law. It contradicts the very foundation of our understanding of what law is, as well as what it can and should be ${ }^{1}$. At the same time, we all know that somehow it works. Even more, it is to some extent exercised in continental Europe, both by national courts (e.g., in Scandinavian countries)

1 Namely the distinction between making law and applying it, see: M. Zirk-Sadowski, Precedens a tzw. decyzja prawotwórcza, „Państwo i Prawo” 1980, z. 6, p. 78. 
and - recently - by the European Court of Justice, whose case law is steadily penetrating national legal systems ${ }^{2}$. Thus, in statutory law countries, a lot of scientific attention has been paid to the Anglo-Saxon doctrine of precedent, as the root of the judge-made law phenomenon. There is a vivid, ongoing debate about the potential of precedent for the statutory legal order ${ }^{3}$.

In Poland, there is a general esteem for precedent as a basis for the judicial application of $\mathrm{law}^{4}$. It is often viewed as a remedy for poor quality legislation and unreflective, mechanical adjudication. Different authors have disagreed, however, on whether and how it could be implemented into the Polish legal order ${ }^{5}$. Some claim that we already live in a system of precedents ${ }^{6}$, although it may be a trivialised or false version of precedents ${ }^{7}$. Others are more sceptical and underline the significant, profound differences between common law and civil law systems, i.e., the different forms of reasoning 8 .

The task we have undertaken in this article can be viewed as a deliberate step back in order to provide some necessary background. We do not ask here about the potential of precedent in the statutory legal order, or to what extent the decisions of statutory law courts are precedents 9 . In fact, we will not even use the term "precedent", in order to avoid any confusion ${ }^{10}$. Instead, our contribution to the debate will be an analysis of the actual ways in which Polish courts refer to earlier judicial decisions in the process of applying law. It is mostly a descriptive, soft-empirical study aimed at grasping the existing judicial practice. Hopefully, it can provide a more solid foundation for future studies and theoretical propositions in this field.

2 M. Koszowski, Anglosaska doktryna precedensu. Porównanie z polska praktyka orzecznicza, Warszawa 2009, pp. 145-147.

3 See, e.g.: Interpreting Precedents. A Comparative Study, eds. D.N. MacCormick, R.S. Summers, Dartmouth 1997; Precedens w polskim systemie prawa, red. A. Śledzińska-Simon, M. Wyrzykowski, Warszawa 2010; other articles in this volume.

4 T. Stawecki, Precedens w polskim porzadku prawnym. Pojęcie $i$ wnioski de lege ferenda, [in:] Precedens w polskim systemie..., pp. 96-98.

5 Tomasz Stawecki, in his very informative article, distinguishes four attitudes towards precedents in Polish legal theory: traditional, skeptical, pragmatic and radical. See: ibidem, pp. 71-73.

6 L. Morawski, Precedens a wykładnia, „Państwo i Prawo” 1996, z. 10, pp. 3-5.

7 E. Łętowska, Czy w Polsce możemy mówić o prawie precedensowym, [in:] Precedens $w$ polskim systemie..., p. 13; J. Zajadło, Precedens rzeczywisty i pozorny, czyli po co prawnikom filozofia prawa, [in:] Precedens w polskim systemie..., p. 25.

8 T. Stawecki, Precedens w polskim porzadku prawnym..., pp. 71-73; idem, Precedens jako zadanie dla nauk prawnych, [in:] Precedens w polskim systemie..., pp. 228-265; M. Koszowski, op. cit., pp. 115-143.

9 See, e.g.: L. Morawski, Precedens a wykładnia, pp. 10-12.

${ }_{10}$ It should be noted that it is an extremely polysemic term, both in common law and civil law environments. See: M. Koszowski, op. cit., pp. 108-109; M. Zirk-Sadowski, op. cit., pp. 70-73. 
We have to begin by making several caveats to outline the context of our research. First of all, Poland is a statutory law country and we dare to say - quite a typical one. Therefore, in our research, Poland serves as a proxy for most civil law countries and we claim that our findings have quite a universal appea ${ }^{11}$. Courts in Poland are supposed to apply law and not to create it. According to the Polish Constitution, their decisions are not a source of law. Thus, they are not formally binding and they cannot act as a legal basis for later judicial decisions. There are a few exceptions to this general rule, but they are limited to particular courts and particular cases, like a legal opinion (e.g., the interpretation of the rule at hand) of the appellate court being binding on a lower court whose decision it overruled. We will not discuss these issues because of their procedural nature.

All this is not to say that earlier judicial decisions have no impact on the judiciary. Of course, it is methodologically problematic to analyse their actual heuristic impact on judges and their decision-making (i.e., psychological motivations). Such an analysis would require employing serious psychological or sociological machinery, which is something we never intended to do. Neither are we interested in a logical reconstruction of the process of judicial decision-making ${ }^{12}$. The important fact is that Polish courts tend to quote earlier judicial decisions more often than not. Therefore, we are interested in the content of written judicial opinions, where courts present justification of their decisions ${ }^{13}$. It is the argumentation used in these opinions that we aim to investigate in this paper ${ }^{14}$.

Lawrence Solan claims that quoting other courts' decisions is a trait of common law judges: "American judges are unrelenting in their citation of earlier decisions as a reason to construe a statute one way or the other. Civil law judges are generally not wedded to this approach"15. As much as we admire his academic work, we find this particular statement to be misleading at best. Civil law judges cite each other extensively ${ }^{16}$. We have conducted a little empirical research in order to verify this thesis. It involved the last 50 judgments of several types of Polish courts:

11 The content of several chapters of the book Interpreting Statutes. A Comparative Study, eds. D.N. MacCormick, R. Summers, Dartmouth 1991, seems to prove this presumption.

12 See: M. Zirk-Sadowski, op. cit., pp. 69-78; L. Leszczyński, Precedens jako źródło rekonstrukcji normatywnej podstawy decyzji stosowania prawa, [in:] Prawo a wartości. Księga jubileuszowa Profesora Józefa Nowackiego, Kraków 2003, pp. 149-162.

13 See: J. Wróblewski, Precedens i jednolitość sadowego stosowania prawa, „Państwo i Prawo” 1971, z. 10, pp. 529-531; L. Leszczyński, op. cit., p. 155.

14 See also: Z. Bankowski, D. Neil MacCormick, R. Summers, J. Wróblewski, On Method and Methodology, [in:] Interpreting Statutes..., pp. 16-18.

15 L.M. Solan, Precedent in statutory interpretation, "North Carolina Law Review" 2016, Vol. 94, p. 1169.

16 It appears that this attitude is not restricted to Poland, but shared by courts in many other civil law countries, including Argentina, Germany, Finland and Italy, see the respective chapters in: Interpreting Statutes... See also: R. Summers, M. Taruffo, Interpretation and Comparative Analysis, [in:] 
Supreme Court, Administrative Supreme Court, Appellate Courts and Regional Administrative Courts. We excluded lower courts' decisions because they are badly underrepresented in legal databases, and therefore their sample would be highly unrepresentative. Next, we calculated how many of the selected decisions include at least one citation of another judicial decision. The numbers are as follow: $66 \%$ for the Supreme Court, 75\% for the Administrative Supreme Court, 78\% for Appellate Courts and $81 \%$ for Regional Administrative Courts.

The above results make it legitimate to say that Polish courts (at least the higher courts) typically refer to earlier decisions. It also shows that - unsurprisingly - this tendency is stronger in lower courts and weaker in the highest ones, which are rightly expected to be more self-contained. Another interesting aspect is the differentiation between common and administrative courts, namely courts that, among other things, review decisions of administration bodies (i.e., imposing taxes, granting licences, etc.). It seems that administrative courts are more prone to quoting other decisions. This can be explained by the fact that this branch of the judiciary deals mostly with purely legal - as opposed to factual - issues. Therefore, it is much more focused on interpretive problems and - consequently - more involved in theoretical debates, which includes quoting and discussing others' opinions.

In this article, we would like to ask three questions concerning the use of earlier judicial decisions by Polish courts as well as offering some preliminary answers. First, how do courts refer to other judicial decisions? Second, when do they do it? And third, why do they do it, and is this frequent tendency justified?

\section{THE "HOW"}

The "how" question includes the form of a quotation and it has several interesting aspects to it. First, a court can refer to one or more judicial decisions. Sometimes the reference is indefinite - a court simply asserts that this or that view has been previously expressed by the judiciary (sometimes this reference is dubbed "line of judgment") ${ }^{17}$. This is, of course, controversial, because a party is usually left with no clue as to where the reference could be found. A second aspect is the technical manner of making the reference. Sometimes courts will offer a word for word quotation from another decision, either using parenthesis or not. More often though, a court would rather paraphrase an excerpt from another court's decision.

Interpreting Statutes..., pp. 487-488. According to those authors: "Together with the statute applied in order to decide the case, precedents are the most frequently used materials in judicial opinions".

17 See, e.g., postanowienie SN z dnia 24 stycznia 2007 r., II KK 267/06. See also: K. Grotkowska, Problematyka argumentu z linii orzeczniczej, [in:] Refleksyjność w prawie. Inspiracje, red. J. Karczewski, M. Żuralska, Warszawa 2015, pp. 53-66. 
This leads to the question: how close is the paraphrase to the original. It is very easy for a referring court to omit a vital passage, either intentionally or accidentally ${ }^{18}$. Sometimes a court will neither quote nor paraphrase, but simply note that there is a judicial decision that supports its opinion. In this case, the decision acts similarly to a footnote in a scientific article. Third, a quotation may occur either before ${ }^{19}$ or after the court's own argumentation ${ }^{20}$, or it may substitute it entirely. Yet another interesting aspect of the "how" question refers to the difference between an opinion and a dissent (or votum separatum). It is not unlikely for a court to quote a dissent from other judicial decisions ${ }^{21}$. This raises important questions about the reasons for the quotation, which will be discussed below.

\section{THE "WHEN"}

Earlier judicial decisions are used in a number of different situations. Due to the enormous amount of empirical data, it is virtually impossible to analyse, or even identify, all of them. Here we will discuss only those that appear to be either the most common, according to our research, or the most theoretically interesting. This list, however, should be treated as a rough typology, not a rigid classification.

\section{As a starting point}

In some instances, an earlier decision may act as a starting point. It means that a court refers to it to set the scene for the actual argumentation. For example, a court may refer to a judicial opinion where some preliminary problem was discussed ${ }^{22}$. It is non-controversial in this particular case, but such a quotation shows the court's

${ }_{18}$ For example: the Supreme Court decided a case on a provision introducing "a non-categoric tenancy option", stating that local administration is not obliged by such a provision (uchwała SN z dnia 25 czerwca 2008 r., III CZP 37/08). That decision was later quoted by a lower court as a crucial argument in a case in which a tenancy was guaranteed by the provision, and the adjective "non-categoric" was simply omitted.

19 For example: "The legal issue that caused the dispute being the essence of the case, was already a subject of recognition by Administrative Supreme Court in cases that led to the following decisions [...]". Wyrok NSA w Warszawie z dnia 27 kwietnia 2017 r., II FSK 896/15.

20 For example: "A similar view has already been expressed in Administrative Supreme Court's decisions [...]”. Wyrok NSA w Warszawie z dnia 25 kwietnia 2017 r., II FSK 207/16.

${ }^{21}$ For example: uchwała SN w pełnym składzie z dnia 28 stycznia 2014 r.; wyrok SN z dnia 25 września 2008 r., II PK 40/08. See also: Z. Tobor, Spór o zdania odrębne, [in:] Wielowymiarowość prawa, Toruń 2014, pp. 215-229.

22 For example, a court may note that a certain regulation has an exceptional character (see: postanowienie SN z dnia 27 kwietnia 2017 r., IV KO 37/17; postanowienie SN z dnia 5 grudnia 2012 r., III KO 102/12, LEX nr 1231575). 
erudition, delineates the current state of legal discourse and acts as a warm-up before the real problem is discussed. Usually, it also limits the area of controversy - a court shows that some problems have already been clarified and need no more scrutinising. Instead, a court may now give its full attention to the issue at hand. We suppose it corresponds with a natural human tendency to deal first with the things we know how to deal with, and only then get down to the things that are truly problematic.

\section{As a proof of doubt}

Another situation is using an earlier decision as a proof of doubt - evidence that a certain regulation is indeed controversial ${ }^{23}$. In some cases, the discrepancy of legal views is a formal prerequisite for applying certain legal institutions, e.g. - in case of the Supreme Court - accepting a cassation complaint ${ }^{24}$ or assembling a larger bench ${ }^{25}$. Most of the time, however, it simply justifies giving more attention to the problem at hand, as well as making use of extraordinary interpretative tools, for instance denying the literal meaning of the statute ${ }^{26}$. This is important due to a widespread interpretive principle, expressed by the Latin maxim: Clara non sunt interpretanda. It states that clear rules are not to be interpreted - they are understood and simply applied. Interpretation comes into play only in case of ambiguity, obscurity and other problems with meaning of the rule at hand. This interpretive principle originates from the work of Jerzy Wróblewski. It was introduced on purely descriptive - as opposed to normative - grounds, and it has a subtle, pragmatic character, often overlooked by its critics. For example, Wróblewski rightly acknowledges that clarity of a rule is not a mere function of its linguistic structure, but results from variety of factors and that the same rule can be clear in one context and unclear in another ${ }^{27}$. Nevertheless, the popular reading of this principle ignores these subtleties and asks for proof of doubt before starting an interpretation ${ }^{28}$. This

23 "Regarding the question presented by the regional court, first and foremost one needs to acknowledge the discrepancy of views both in legal doctrine and in case law" (postanowienie SA w Łodzi z dnia 20 lipca 2011 r., II AKz 380/11; see also: uchwała NSA w Warszawie 7 sędziów z dnia 24 listopada 2008 r., II FPS 4/08; wyrok SA w Białymstoku z dnia 7 kwietnia 2016 r., III AUa 1164/15; wyrok SA w Katowicach z dnia 3 lutego 2011 r., II AKa 476/10).

24 Art. $398^{9}$ k.p.c., see: postanowienie SN z dnia 23 kwietnia 2015 r., I CSK 691/14.

25 Art. 60 ust. 1 ustawy z dnia 23 listopada 2002 r. o Sądzie Najwyższym.

26 For example: wyrok NSA w Warszawie z dnia 4 lutego 2015 r., I OSK 1248/13; wyrok WSA w Olsztynie z dnia 12 września 2013 r., I SA/Ol 370/13.

27 See: J. Wróblewski, Pragmatyczna jasność prawa, „Państwo i Prawo” 1988, z. 4; A. Grabowski, Clara non sunt interpretanda vs. omnia sunt interpretanda. A never-ending controversy in Polish legal theory?, "Revus” 2015, Vol. 27; K. Płeszka, Wykładnia rozszerzająca, Warszawa 2010, pp. 187-235.

${ }^{28}$ For example: wyrok SN z dnia 16 maja 2003 r., II KK 65/03. 
is where the discussed way of using earlier decisions is especially useful, as there is no better proof of legal controversy than a disagreement in the judiciary resulting in two or more contradictory decisions ${ }^{29}$.

\section{As a methodological guide}

Earlier decisions are also used as a methodological guides. A court would often refer to other decisions in order to justify applying a certain method of interpretation. In Poland, the biggest controversy in this respect is the arguable primacy of "linguistic interpretation". According to the proponents of this principle, linguistic interpretation (i.e., the analysis of the meaning of words and grammar used in a provision, as well as using some formal logic reasoning) is what any interpretive activity should always begin with. Only if this method proves insufficient, opening the door to further investigations, is a court allowed to refer to extra-linguistic factors, be they contextual, systematic, historical, functional or purposive ${ }^{30}$. The opposing principle states that a court should always make use of all available interpretive tools because it is the only way to guarantee the proper results of an interpretation. Constraining courts to a purely linguistic method is often misleading and renounces a lot of relevant factors ${ }^{31}$. Choosing an interpretive methodology is, therefore, a crucial decision. Not surprisingly, courts often refer to the authority of other courts to justify their choice. The same applies to the methodologies of evaluating evidence. For lower courts, which are more likely to deal with evidentiary, rather than interpretive, problems, this choice is even more important. For example, there are two competing lines of judgment concerning the problem of ascribing an intention to kill in Polish criminal law. According to one, it can be inferred simply from the use of a dangerous tool, according to another - it cannot. As usual, it is up to the court to choose between them.

29 For example: "Legal practice experiences indeterminacy (vagueness) of the notion of [...], and it is proved by numerous statements by legal doctrine and rich case law of administrative courts devoted to this issue". Wyrok WSA w Olsztynie z dnia 4 grudnia 2012 r., II SAB/O1 160/12.

30 See: L. Morawski, Zasady wyktadni prawa, Toruń 2010, p. 72. As the Supreme Court pointed: "[...] the most important interpretive directive of preferences is, widely accepted by the judiciary and legal doctrine, the principle of linguistic interpretation primacy and the subsidiary use of systematic and functional interpretation. This principle, though not absolute, allows for different methods of interpretation only when the result of linguistic interpretation is absurd, iniquitous or leads to irrational consequences". Uchwała SN z dnia 12 stycznia 2010 r., III CZP 119/09.

${ }_{31}$ See: A. Bielska-Brodziak, Interpretacja tekstu prawnego na przykładzie orzecznictwa podatkowego, Warszawa 2009, pp. 197-208; M. Zieliński, Wykładnia prawa. Zasady, reguły, wskazówki, Warszawa 2002, p. 275. "In the process of interpreting law, one cannot ignore the systematic or functional interpretation and restrict himself to linguistic interpretation only" - wyrok NSA w Warszawie z dnia 17 grudnia 2009 r., II FSK 1121/08. See also: wyrok WSA w Gdańsku z dnia 6 marca 2013 r., II SA/Gd 718/12; wyrok NSA w Warszawie z dnia 13 czerwca 2014 r., I FSK 838/13. 


\section{As a dictionary}

Very often, earlier court decisions are used as specific sort of dictionary. A court defines the meaning of a provision with reference to earlier decisions ${ }^{32}$. Apparently, this practice is common in the American judiciary as well ${ }^{33}$. This meaning is often called "juristic" as opposed to both "ordinary" and "legal" 34 . Of course, judicial decisions are not dictionaries and judges are not lexicographers. Most court decisions are highly situational, and so is the meaning constructed for their purposes. At the same time, the use of statutory terms by earlier courts can be viewed, according to the causal theory of reference by Kripke and Putnam, as "multiple groundings" of their meaning. Analysing those previous uses allows an interpreter to track the evolution of the meaning of legal terms ${ }^{35}$.

The next two types of use can be classified as subtypes of the above-mentioned one.

\section{As a vagueness killer}

Sometimes earlier decisions are used by courts to fight the vagueness of statutory language ${ }^{36}$. It can appear in two forms: a court may refer to an earlier decision as proof that a given object does or does not fall into the scope of a vague expression, e.g., that a screwdriver is a "dangerous tool" ${ }^{37}$. However, such a reference may also be made in order to introduce more specific, extra-statutory conditions, making it easier for a court to classify certain objects into a given category, e.g., that the evaluation of whether something is "a dangerous tool" should be made based on objective and inherent features of that object, and not the manner of its use $^{38}$. What is controversial here is the fact that vagueness in legal language is generally introduced intentionally by the legislature, in order to provide flexibility

32 For example: wyrok SN z dnia 10 lipca 2013 r., IV KK 87/13; wyrok NSA w Warszawie $\mathrm{z}$ dnia 5 maja 2017 r., II FSK 1041/15.

33 L.M. Solan, Precedent in statutory..., p. 1186.

34 See: A. Bielska-Brodziak, op. cit., pp. 56-57; postanowienie SA w Białymstoku z dnia 10 kwietnia 1991 r., II AKz 13/91; uchwała SN 7 sędziów z dnia 21 września 2005 r., I KZP 29/05.

35 M. Matczak, Teoria precedensu czy teoria cytowań? Uwagi o praktyce odwołań do wcześniejszych orzeczeń sądowych w świetle teorii wielokrotnych ugruntowań ferenda, [in:] Precedens w polskim systemie..., pp. 116-122.

${ }^{36}$ On the topic of the vagueness of legal language, see for example: T. Endicott, Vagueness in law, Oxford 2001; A. Marmor, Varieties of Vagueness in the Law, "University of Southern California" 2013 (Working Paper 89); M.L. Solan, The Language of Statutes. Laws and Their Interpretation, Chicago-London 2010.

37 For example: postanowienie SN z dnia 1 października 2008 r., IV KK 88/08.

38 For example: wyrok SA w Katowicach z dnia 24 października 2013 r., II AKa 238/13, LEX nr 1400248. 
of statutory text ${ }^{39}$. Sometimes it looks like courts are trying to limit this flexibility, which is not necessarily their role.

\section{As an ambiguity-solver}

Another dictionary-like use is when a court resolves an ambiguity of statutory language. By ambiguity, we mean a situation in which there is more than one legitimate reading of a given provision. The source of ambiguity could either be lexical or syntactic. This situation differs from the previous one because ambiguity is never intended by the legislature - it is rather considered a drafting error ${ }^{40}$. Therefore, when a court refers to an earlier decision in order to resolve ambiguity, i.e., to decide how the conjunctive word "AND" should be construed in a given sentence $^{41}$, it does amend the statute ${ }^{42}$. One might argue that this is also not its role in the legal system, and yet firstly: such an amendment is necessary for the rule to be applied in any way, and secondly: it can be perfectly in line with legislative intent, which was simply erroneously expressed.

\section{As legal rules}

Courts use other decisions as legal rules when they start to analyse the text of the opinion as if it was law, instead of analysing the statute itself. To some extent, all of the ways of use mentioned above have this element to them, but sometimes it is particularly apparent. There is an illustrative example of such a case: in Polish law, there is a statute governing the procedure of political vetting called lustracjacandidates for public officials have to either admit or deny that they used to collaborate with the communist security agendas. These declarations are later verified by a court. The statutory definition of this collaboration is not very precise. However, over the years, the courts - with significant help from the Polish Constitutional Court - have adopted many auxiliary rules and conditions defining what conduct can be counted as "collaboration". Nowadays, when recognising vetting cases, courts usually cite, analyse and interpret those judge-made rules and conditions, rather than the statute itself ${ }^{43}$. This is a civil law version of the phenomenon called

39 See: J. Wróblewski, Statutory Interpretation in Poland, [in:] Interpreting Statutes ..., pp. 262 263; Z. Tobor, W poszukiwaniu intencji prawodawcy, Warszawa 2013, pp. 189-212.

40 See: Z. Tobor, $W$ poszukiwaniu intencji..., pp. 179-188.

41 Wyrok SN z dnia 2 marca 2015 r., IV KK 382/14, LEX nr 1654750.

42 As Lawrence Solan puts it (quoting Justice Black): "[...] courts must resolve ambiguities in statutes, even when such resolution is inseparable from a policy decision that, in an ideal world, would have been the legislature's to make". L.M. Solan, Precedent ..., p. 1177 (see Boys Mkts., Inc., 398 U.S. at 256-58 [J. Black, dissenting]).

43 Wyrok SN z dnia 29 stycznia 2016 r., IV KK 326/15. 
"textualisation of precedent", described in American jurisprudence ${ }^{44}$. It is not easy to evaluate this phenomenon. It can be both beneficial and detrimental for the legal system. It is unarguably beneficial when the courts clarify statutory language that way, for instance, creating necessary classifications and definitions. At the same time, substituting judicial language for that of the legislature creates important questions about the role of judiciary in a statutory law order ${ }^{45}$.

\section{THE "WHY"}

Let us now turn to the third question, the question of "why". At this point, it is hardly possible to avoid comparisons with the Anglo-Saxon doctrine of judicial precedent. This doctrine is often described as a way of ensuring stability and coherence of adjudication - through the doctrine of stare decisis ${ }^{46}$. The use of precedents in statutory interpretation is also based mostly on these two key values ${ }^{47}$. There is no doubt that these values undergird civil law culture as well, and quoting earlier decisions is often seen as a means of advancing them ${ }^{48}$. However, our study suggests that citing earlier judicial decisions by courts does not always fulfill, nor even correspond with, stability and coherence.

First of all, it should be stressed that in Poland (as in most civil law countries) there is no "statutory stare decisis", namely a principle whereby precedents in statutory cases are not to be overturned lightly, known in common law countries ${ }^{49}$. There is no formal binding of earlier judicial decisions; they act merely as interpre-

44 See: P. Tiersma, The Textualisation of Precedent, "Notre Dame Law Review" 2006, Vol. 82, pp. 1187-1278. According to Lawrence Solan, it is a departure from classical common law analysis, in which the holding is considered to have precedential effect, but not the reasoning. See: L.M. Solan, Precedent..., p. 1216. Indeed, civil law judges are usually more interested in the reasoning (argumentation) of other courts, not the holdings.

45 Ibidem, p. 1219.

46 See: M. Koszowski, op. cit., pp. 18-19; T. Stawecki, Precedens jako zadanie..., pp. 232-235, 239.

47 L.M. Solan, Precedent ..., p. 1220. According to Lawrence Solan, there are four main reasons why American courts rely on statutory precedents. First and foremost, to ensure coherence in the application of law. Second, to demonstrate that an argument falls within the culture of legal reasoning and thus is entitled to some level of deference. Third, to develop principles that courts wish to follow so that interpretation proceeds in a path-dependent manner. Fourth, to introduce a methodological stare decisis. See: ibidem pp. 1185-1187. See also: R.H. Fallon, The Meaning of Legal "Meaning" and Its Implications for Theories of Legal Interpretation, "University of Chicago Law Review" 2015, Vol. 82(3), p. 1251.

48 Ibidem, p. 1175; J. Wróblewski, Precedens i jednolitość sq̨dowego stosowania ..., pp. 532-533; M. Zirk-Sadowski, op. cit., p. 78.

49 L.M. Solan, Precedent ..., pp. 1175-1178. 
tive arguments (hence they are sometimes referred to as "persuasive precedents" ${ }^{50}$ ). Simply put: "In citing each other, judges signal to readers that »this is something that has been said before«. When they cite multiple cases, they are signaling, »this is something that has been said over and over again «"51. That is it. In addition, the fundamental distinction between ratio decidendi and obiter dicta is completely unknown ${ }^{52}$. Virtually any piece of an earlier opinion can be quoted in a later decision. As a result instead of the doctrine of precedents, what we have is merely a practice of citing judicial decisions ${ }^{53}$.

As mentioned, most of the time Polish courts are interested in the argumentation of another court, rather than in the decision itself $^{54}$. This explains, among other things, why courts have no problems referring to dissenting opinions, or why they tend to refer to large numbers of other decisions ("lines of judgment"), whereas they could be content with just a single, suitable opinion ${ }^{55}$. Of course, in many cases the distinction here is unimportant. From a certain argumentation, a certain decision is directly derived ${ }^{56}$. However, this approach ignores the differences between the facts of the cases. It often relies on wordings stripped of the relevant context, and one should be very careful when considering part of the argumentation detached from the facts of the case. It may be obvious to a common law judge, but it is not so for a statutory law judge ${ }^{57}$. This practice is also very susceptible to selective citations, namely picking only those decisions that support the desired conclusion and overlooking all those that do not. It is no secret that for many crucial legal regulations there are at least two competing "lines of judgment" (or "lines of decisions" ${ }^{\text {") }}$ ) and the choice between them is more or less arbitrary ${ }^{59}$.

${ }^{50}$ R. Summers, M. Taruffo, op. cit., pp. 487-489; J. Zajadło, op. cit., p. 27; T. Stawecki, Precedens $w$ polskim porzadku prawnym ..., p. 80.

51 L.M. Solan, Precedent ..., p. 1220.

52 R. Summers, M. Taruffo, op. cit., p. 489.

53 M. Matczak, op. cit., p. 99; M. Koszowski, op. cit., pp. 129-143; T. Stawecki, Precedens w polskim porządku prawnym ..., p. 68. See also: M. La Torre, E. Pattaro, M. Taruffo, Statutory Interpretation in Italy, [in:] Interpreting Statutes..., p. 228.

${ }_{54}$ M. Matczak, op. cit., p. 117.

55 R. Summers, M. Taruffo, op. cit., p. 489; M. Koszowski, op. cit., pp. 139-140.

56 Z. Bankowski, D. Neil MacCormick, R. Summers, J. Wróblewski, op. cit., pp. 16-17.

57 M. Koszowski, op. cit., pp. 118-119; E. Łętowska, op. cit., p. 13; T. Stawecki, Precedens w polskim porzadku prawnym ..., pp. 67-68.

58 J. Wróblewski, Statutory Interpretation..., p. 279; M. Koszowski, op. cit., p. 139 (noting that "line of judgment" should not be mistaken for the term "leading case", though there are some similarities between their meanings).

59 See: R. Summers, M. Taruffo, op. cit., p. 489; M. Koszowski, op. cit., p. 140. “[...] if legislative history comes from choosing friends at a cocktail party, citation of case precedent comes from a president choosing among friends at an inaugural ball”- L.M. Solan, Precedent ..., p. 1169, footnote 13. 


\section{CONCLUSIONS}

Just as with all interpretive tools - quoting other decisions can be employed for many various tasks. In the end, it is the responsibility of judges to use it in such a way as to ensure further stability and coherence ${ }^{60}$. They should always keep in mind that it can also achieve different values, not necessarily desirable in the realm of statutory law ${ }^{61}$.

\section{REFERENCES}

Bankowski Z., Neil MacCormick D., Summers R., Wróblewski J., On Method and Methodology, [in:] Interpreting Statutes. A Comparative Study, eds. D.N. MacCormick, R. Summers, Dartmouth 1991.

Bielska-Brodziak A., Interpretacja tekstu prawnego na przykładzie orzecznictwa podatkowego, Warszawa 2009.

Endicott T., Vagueness in law, Oxford 2001.

Fallon R.H., The Meaning of Legal "Meaning” and Its Implications for Theories of Legal Interpretation, "University of Chicago Law Review" 2015, Vol. 82(3).

Flemming-Kulesza T., Czy w Polsce możemy mówić o prawie precedensowym?, [in:] Precedens w polskim systemie prawa, red. A. Śledzińska-Simon, M. Wyrzykowski, Warszawa 2010.

Grabowski A., Clara non sunt interpretanda vs. omnia sunt interpretanda. A never-ending controversy in Polish legal theory?, "Revus" 2015, Vol. 27.

Grotkowska K., Problematyka argumentu z linii orzeczniczej, [in:] Refleksyjność w prawie. Inspiracje, red. J. Karczewski, M. Żuralska, Warszawa 2015.

Interpreting Precedents. A Comparative Study, eds. D.N. MacCormick, R.S. Summers, Dartmouth 1997.

Interpreting Statutes. A Comparative Study, eds. D.N. MacCormick, R. Summers, Dartmouth 1991.

Koszowski M., Anglosaska doktryna precedensu. Porównanie z polska praktyka orzecznicza, Warszawa 2009.

La Torre M., Pattaro E., Taruffo M., Statutory Interpretation in Italy, [in:] Interpreting Statutes. A Comparative Study, eds. D. Neil MacCormick, R. Summers, Dartmouth 1991.

Leszczyński L., Precedens jako źródło rekonstrukcji normatywnej podstawy decyzji stosowania prawa, [in:] Prawo a wartości. Księga jubileuszowa Profesora Józefa Nowackiego, Kraków 2003.

Łętowska E., Czy w Polsce możemy mówić o prawie precedensowym, [in:] Precedens w polskim systemie prawa, red. A. Śledzińska-Simon, M. Wyrzykowski, Warszawa 2010.

Marmor A., Varieties of Vagueness in the Law, "University of Southern California" 2013 (Working Paper 89).

${ }^{60}$ T. Flemming-Kulesza, Czy w Polsce możemy mówić o prawie precedensowym?, [in:] Precedens w polskim systemie..., p. 16. As Jerzy Wróblewski put it: “[...] there are »good« and »bad« precedents”. See: J. Wróblewski, Precedens i jednolitość sądowego stosowania ..., p. 533.

${ }^{61}$ See: L.M. Solan, Precedent..., pp. 1133-1134. Marcin Matczak goes as far as claiming that citing earlier decisions furthers not stability, but evolution of the meaning of statutory language. See: M. Matczak, op. cit., p. 99. 
Matczak M., Teoria precedensu czy teoria cytowań? Uwagi o praktyce odwołań do wcześniejszych orzeczeń sadowych $w$ świetle teorii wielokrotnych ugruntowań ferenda, [in:] Precedens w polskim systemie prawa, red. A. Śledzińska-Simon, M. Wyrzykowski, Warszawa 2010.

Morawski L., Precedens a wyktadnia, „Państwo i Prawo” 1996, z. 10.

Morawski L., Zasady wyktadni prawa, Toruń 2010.

Płeszka K., Wykładnia rozszerzająca, Warszawa 2010.

Precedens w polskim systemie prawa, red. A. Śledzińska-Simon, M. Wyrzykowski, Warszawa 2010.

Solan L.M., Precedent in statutory interpretation, "North Carolina Law Review" 2016, Vol. 94.

Solan L.M., The Language of Statutes. Laws and Their Interpretation, Chicago-London 2010.

Stawecki T., Precedens jako zadanie dla nauk prawnych, [in:] Precedens w polskim systemie prawa, red. A. Śledzińska-Simon, M. Wyrzykowski, Warszawa 2010.

Stawecki T., Precedens w polskim porzadku prawnym. Pojęcie $i$ wnioski de lege ferenda, [in:] Precedens w polskim systemie prawa, red. A. Śledzińska-Simon, M. Wyrzykowski, Warszawa 2010.

Summers R., Taruffo M., Interpretation and Comparative Analysis, [in:] Interpreting Statutes. A Comparative Study, eds. D. Neil MacCormick, R. Summers, Dartmouth 1991.

Tiersma P., The Textualisation of Precedent, "Notre Dame Law Review" 2006, Vol. 82.

Tobor Z., Spór o zdania odrębne, [in:] Wielowymiarowość prawa, Toruń 2014.

Tobor Z., W poszukiwaniu intencji prawodawcy, Warszawa 2013.

Wróblewski J., Pragmatyczna jasność prawa, „Państwo i Prawo” 1988, z. 4.

Wróblewski J., Precedens i jednolitość sq̨dowego stosowania prawa, „Państwo i Prawo” 1971, z. 10.

Wróblewski J., Statutory Interpretation in Poland, [in:] Interpreting Statutes. A Comparative Study, eds. D.N. MacCormick, R. Summers, Dartmouth 1991.

Zajadło J., Precedens rzeczywisty i pozorny, czyli po co prawnikom filozofia prawa, [in:] Precedens w polskim systemie prawa, red. A. Śledzińska-Simon, M. Wyrzykowski, Warszawa 2010.

Zieliński M., Wykładnia prawa. Zasady, reguty, wskazówki, Warszawa 2002.

Zirk-Sadowski M., Precedens a tzw. decyzja prawotwórcza, „Państwo i Prawo” 1980, z. 6.

\section{STRESZCZENIE}

W niniejszym artykule autorzy analizują sposoby wykorzystania wcześniejszych orzeczeń w procesie stosowania prawa przez polskie sądy. Rozważają kolejno trzy aspekty tego zagadnienia. Po pierwsze, sposób, w jaki orzeczenia są powoływane (np. cytat, parafraza itd.). Po drugie, sytuacje, w których sądy odwołują się do innych orzeczeń (np. jako punkt wyjścia, jako dowód wątpliwości interpretacyjnych, jako narzędzie usuwające nieostrość czy wieloznaczność przepisu, jako wskazówka metodologiczna, jako podstawa prawna orzeczenia itd.). Po trzecie, powody, dla których odwołania te się pojawiają. We wnioskach autorzy zestawiają wyniki analizy z praktyką powoływania orzeczeń sądowych charakterystyczną dla krajów prawa precedensowego i wskazują na podstawowe różnice.

Slowa kluczowe: orzecznictwo; argumentacja; precedens 